\title{
The Role of the Hedgehog Pathway in Chemoresistance of Gastrointestinal Cancers
}

\author{
Yabing Liang ${ }^{1}$, Ling Yang ${ }^{1, *}$ and Jingwu Xie ${ }^{2, *}$ \\ 1 Inner Mongolia Key Laboratory of Medical Cell Biology, Clinical Medical Research Center of the Affiliated \\ Hospital, Inner Mongolia Medical University, Hohhot 010050, China; 15149009099@163.com \\ 2 Wells Center for Pediatric Research, Department of Pediatrics, Indiana University School of Medicine, \\ Indianapolis, IN 46202, USA \\ * Correspondence: yanglingshmily@126.com (L.Y.); jinxie@iu.edu (J.X.)
}

check for updates

Citation: Liang, Y.; Yang, L.; Xie, J. The Role of the Hedgehog Pathway in Chemoresistance of Gastrointestinal Cancers. Cells 2021, 10, 2030. https:// doi.org/10.3390/cells10082030

Academic Editors: Maria

Domenica Castellone, Xiaoyan Zheng and Stephen Yarwood

Received: 9 June 2021

Accepted: 6 August 2021

Published: 9 August 2021

Publisher's Note: MDPI stays neutral with regard to jurisdictional claims in published maps and institutional affiliations.

Copyright: (c) 2021 by the authors. Licensee MDPI, Basel, Switzerland. This article is an open access article distributed under the terms and conditions of the Creative Commons Attribution (CC BY) license (https:// creativecommons.org/licenses/by/ $4.0 /)$.

\begin{abstract}
The hedgehog pathway, which plays a significant role in embryonic development and stem cell regulation, is activated in gastrointestinal cancers. Chemotherapy is widely used in cancer treatment. However, chemoresistance becomes a substantial obstacle in cancer therapy. This review focuses on the recent advances in the hedgehog pathway's roles in drug resistance of gastrointestinal cancers and the novel drugs and strategies targeting hedgehog signaling.
\end{abstract}

Keywords: the hedgehog pathway; chemotherapy; resistance; gastric cancer; colorectal cancer; pancreatic cancer

\section{Introduction}

The hedgehog $(\mathrm{HH})$ pathway plays a crucial role in embryonic development, tissue homeostasis, and carcinogenesis [1,2]. HH ligands activate signaling by binding to receptor patched 1 homolog (PTCH1). In the absence of HH ligands, PTCH1 prevents smoothened (SMO) from transducing a signal to the downstream glioma-associated oncogene homolog (GLI) transcription factors. HH ligands bind to PTCH1, and relieve PTCH1's inhibition on SMO, allowing SMO to signal downstream effectors GLI, which activates the target genes via specific genomic DNA sequences (TGGGTGGTC) $[3,4]$.

Activation of GLI proteins via the HH-PTCH1-SMO axis is regarded as the canonical $\mathrm{HH}$ signaling pathway. In addition to the canonical pathway, some molecules can bypass the ligand-receptor signaling axis to activate GLI, and these types of regulation are regarded as non-canonical $\mathrm{HH}$ signaling. Non-canonical $\mathrm{HH}$ signaling is found in malignant diseases. KRAS signaling [5,6], transforming growth factor $\beta$ (TGF $\beta$ ) [7], AKT [8], protein kinase $\mathrm{C}$ (PKC) [9], and SOX2-bromodomain-containing protein 4(BRD4) [10] are reported to regulate $\mathrm{HH}$ signaling via non-canonical pathways.

Chemotherapy is widely used in cancer treatment, and significant improvement is achieved in the prognosis of patients. However, not all patients benefit from it. Chemoresistance becomes a substantial obstacle in cancer therapy due to intrinsic resistance, which occurs at the beginning or even before the treatment, or acquired resistance after initial response to treatment, resulting in relapse [11,12]. Platinum, 5-Fluorouracil (5-FU), and gemcitabine are the most commonly used drugs in the chemotherapy of gastric, colorectal, and pancreatic cancers, and the underlined mechanisms of drug resistance have been studied. Mechanisms of chemoresistance include cancer stem cells(CSCs), tumor microenvironment, and ATP-binding cassette $(A B C)$ transporter family proteins [13-15].

Our group studied drug resistance in gastrointestinal cancers and found the $\mathrm{HH}$ pathway contributes to drug resistance. This review focuses on recent advances that link the $\mathrm{HH}$ pathway to drug resistance in gastrointestinal cancers and examines novel drugs and strategies that may overcome $\mathrm{HH}$-mediated drug resistance. 


\section{Cancer Stem Cells}

CSCs are a subpopulation of cancer cells capable of self-renewal, metastasis, and treatment resistance. Evidence indicates that CSCs are involved in chemoresistance and relapse of cancers. As a classical developmental pathway, the $\mathrm{HH}$ pathway supports the maintenance and survival of CSCs (Figure 1) [16]. Therefore, targeting the $\mathrm{HH}$ pathway may be a promising strategy in eradicating CSCs $[17,18]$.

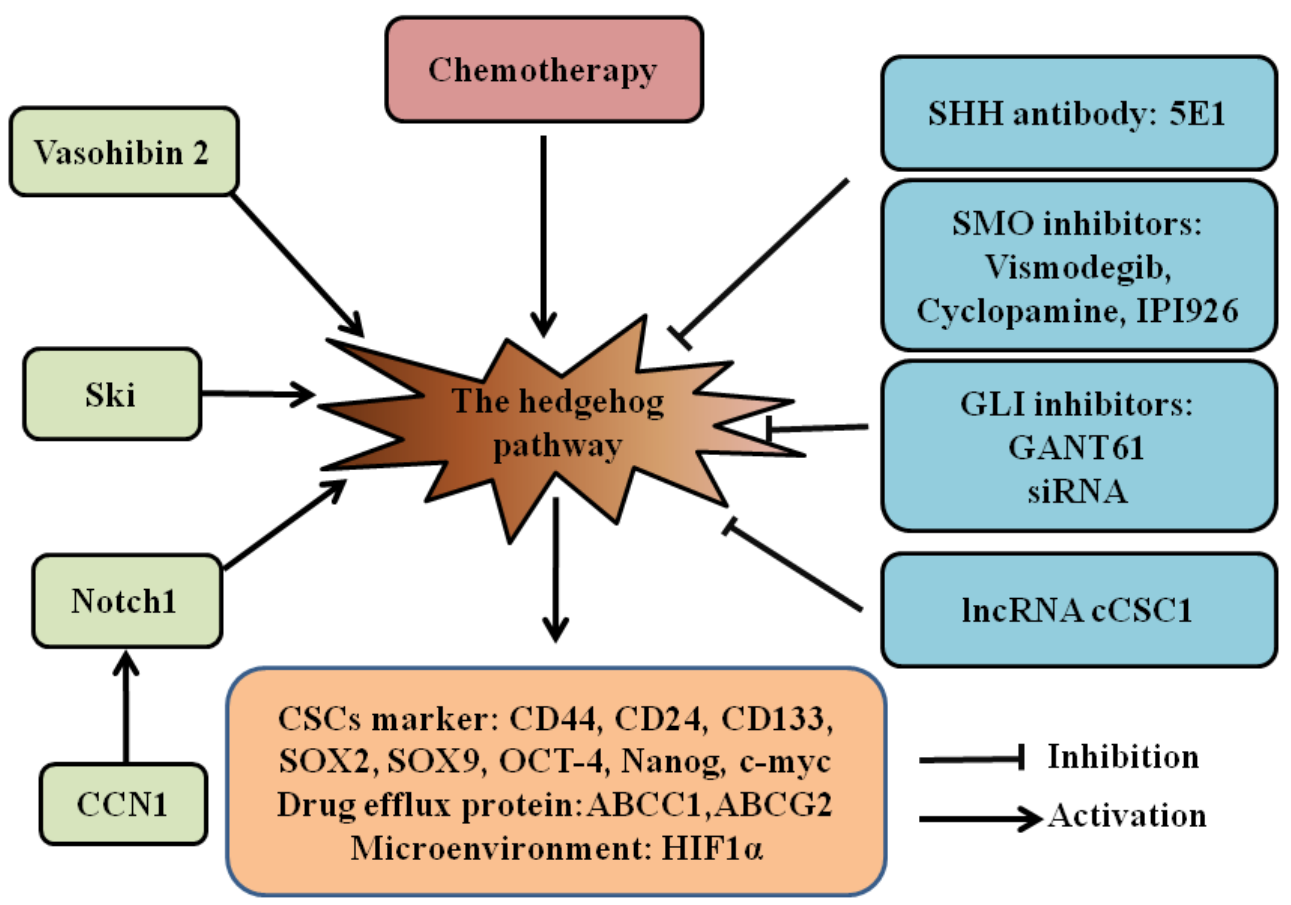

Figure 1. The HH pathway in gastrointestinal CSCs. The role of the hedgehog pathway in drug resistance of gastrointestinal CSCs and inhibitors for hedgehog signaling is summarized. In gastrointestinal CSCs, CCN1, Notch1, Ski, Vasohibin2, and chemotherapy can activate the HH pathway to increase stemness through upregulating CD44, CD24, CD133, SOX2, SOX9, OCT-4, Nanog, and $\mathrm{c}-\mathrm{myc}$, to increase drug resistance by elevating the expression of the drug efflux protein $\mathrm{ABCC} 1$ and ABCG2, and to adapt to hypoxia via high expression of HIF1 $\alpha$. The HH inhibitors (5E1, vismodegib, cyclopamine, IPI926, GANT61, GLI siRNA, and lncRNA cCSC1) can attenuate these processes. Hedgehog (HH); cancer stem cells (CSCs); cellular communication network factor 1 (CCN1); ATPbinding cassette subfamily $\mathrm{C}$ member 1 (ABCC1); ATP-binding cassette subfamily G member 2 (ABCG2); hypoxia inducible factor $1 \alpha(\mathrm{HIF} 1 \alpha)$.

We and others have discovered that the $\mathrm{HH}$ pathway is activated in gastric CSCs, which is characterized by a side population [19], cell surface marker CD44 [20,21], CD24, CD133 [22], aldehyde dehydrogenase (ALDH) [23], and Musashi-1 [24]. This pathway is essential for maintaining the viability, motility, and chemotherapeutic resistance of gastric CSCs. Recently, SOX2-positive gastric cancer cells were found to present CSC properties [25]. The CSCs with activated $\mathrm{HH}$ signaling contributed to chemotherapy resistance in variant kinds of drugs, such as platinum [19,20], 5-Fu [20,25,26], paclitaxel [27], and doxorubicin [24]. Our group found that the GLI1 protein interacted with the promoter of ATP-binding cassette subfamily G member 2 (ABCG2)through a GLI-binding consensus site in gastric CSCs [19]. ABCG2 is a well-known drug efflux protein and transports small molecules, including chemotherapeutic drugs. This mechanism may explain why gastric CSCs enriched with the HH pathway are more resistant to chemotherapy.

The HH pathway also plays a vital role in colorectal CSCs. Colorectal CSCs showed elevated expression of the genes downstream of $\mathrm{HH}$ signaling [28,29], and the $\mathrm{HH}$ pathway inhibitor reduced the expression of stemness markers and resistance to 5-FU and platinum 
in colorectal CSCs [28,30]. Activation of $\mathrm{HH}$ signaling is associated with high expression of CD133, SOX9, hypoxia inducible factor $1 \alpha$ (HIF1 $\alpha$ ), and ATP-binding cassette subfamily C member 1 (ABCC1) in colorectal CSCs $[29,30]$. IncRNA-cCSC1 inhibited the self-renewal of the colorectal CSCs and reduced their drug resistance to 5-FU by regulating the $\mathrm{HH}$ pathway [31]. Culturing three-dimensional organoids becomes a valuable tool to study CSCs by enriching CSCs from cancer cell lines and tissues. Usui et al. established an airliquid interface (ALI) method to culture organoids from colorectal cancers. These organoids showed resistance to 5-FU and Irinotecan. The HH pathway inhibitors (GANT61) decreased the organoids' cell viability and inhibited the expression of the CSC markers c-Myc, CD44, and Nanog [32].

Activation of the $\mathrm{HH}$ pathway is also found in pancreatic CSCs. Inhibiting $\mathrm{HH}$ signaling downregulates Bmi-1 [33], CD133 [34], SOX2 [35], and ABCG2 [33], leading to the reversal of gemcitabine resistance. Hh signaling is also associated with cellular communication network factor 1 (CCN1), Notch1 [36], Vasohibin 2 (VASH2) [37], and Ski [38] in pancreatic cancer. The HH pathway can be activated by VASH2, Ski, and active Notch1 in pancreatic CSCs and contributes to maintain stemness and promote epithelialmesenchymal transition (EMT) [36-38]. Studies also found that combined inhibition of $\mathrm{HH}$ and mammalian target of rapamycin (mTOR) signaling effectively reduced pancreatic CSCs $[34,39]$.

Since the $\mathrm{HH}$ pathway participates in CSCs, targeting the $\mathrm{HH}$ pathway is a promising targeted therapy (Figure 1). In a Phase II trial of advanced gastric cancers, chemotherapy combined with vismodegib was associated with improved survival in patients with high CD44 expression [20]. The sonic hedgehog (SHH) antibody 5E1 reduced the self-renewing capacity of gastric tumorsphere cells and enhanced the efficacy of chemotherapeutic drugs in tumorsphere cells in vitro and in vivo [22]. The SMO inhibitors cyclopamine [22,28,33], IPI-926 [27], and vismodegib [20,24] decreased the stemness of gastrointestinal CSCs in vitro and in vivo. GLI inhibitor GANT61 increased doxorubicin-induced apoptosis in gastric CSCs [24] and regulated drug resistance of colorectal CSCs [29,30]. GANT61 also reduced the sphere formation and cell viability of pancreatic CSCs [34]. Targeting GLI1 using GLI1 siRNA nanoparticles significantly decreased GLI1 protein expression, inhibited gastric CSC tumor spheroid and colony formation, and suppressed cell migration and invasion [40]. Different groups use different types of inhibitors for their studies, from inhibition of HH and SMO to GLI. Moreover, some studies found GLI, not SMO, activated $\mathrm{HH}$ signaling in CSCs [34,41]. Therefore, identifying how the $\mathrm{HH}$ pathway is activated, caused by $\mathrm{HH} / \mathrm{SMO}$, or regulated by other pathways, may help us make sure which component should be targeted and if combined inhibition of the crosstalking pathway is also needed.

\section{Tumor Microenvironment}

There is mounting evidence to indicate that the tumor microenvironment (TME) is essential for carcinogenesis, angiogenesis, invasiveness, and immune escape [17,42,43]. The TME includes active fibroblasts, immune cells, endothelial cells, neurons, adipocytes, and the extracellular matrix. A hypoxic microenvironment-derived HIF1 $\alpha$ and cancerassociated fibroblast (CAF)-derived TGF- $\beta 2$ activated the expression of the $\mathrm{HH}$ transcription factor GLI2 in colorectal CSCs, resulting in increased stemness and resistance to chemotherapy (Figure 2) [44]. 


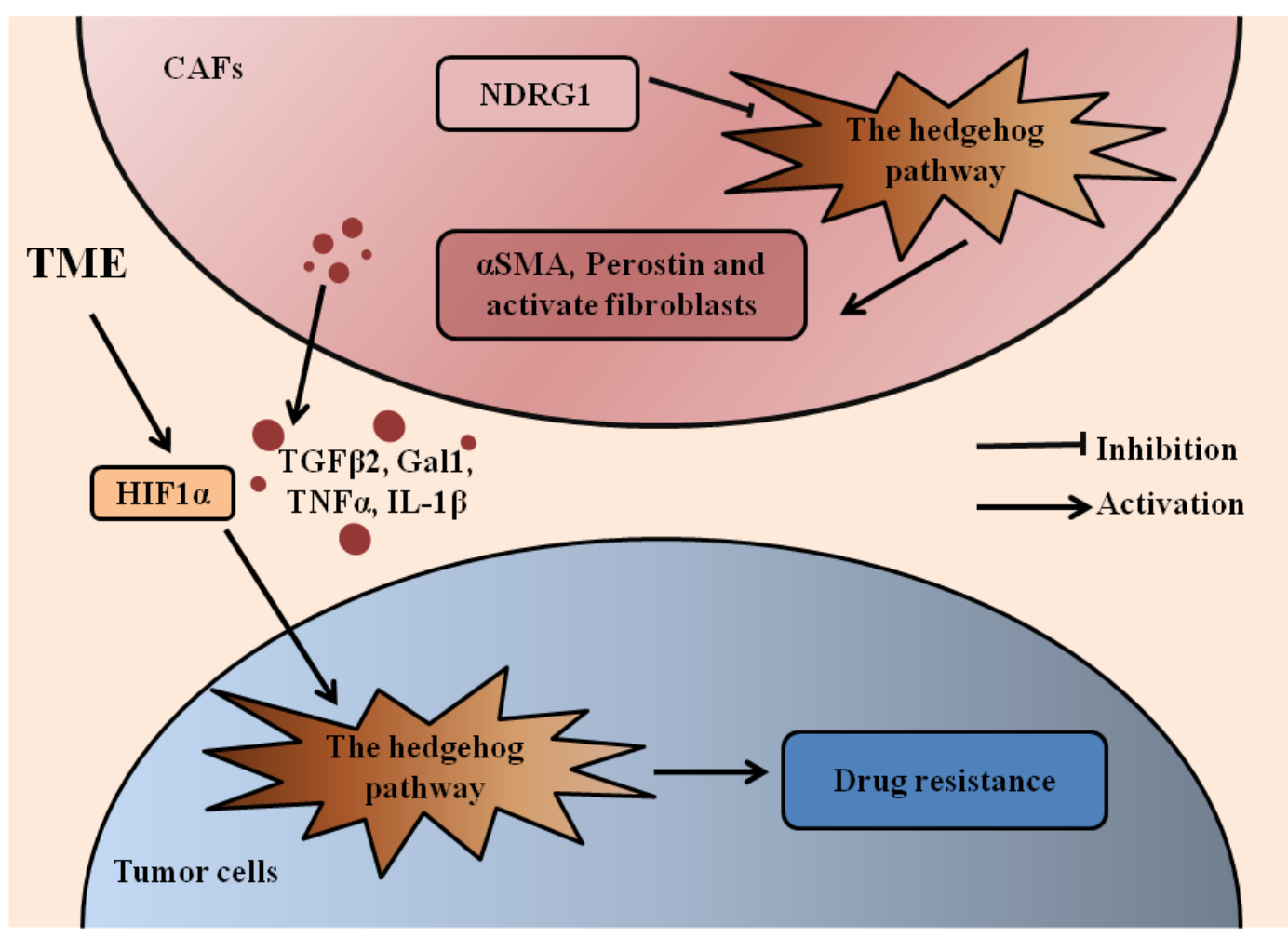

Figure 2. The HH pathway in gastrointestinal cancers and TME. The role of HH signaling in drug resistance of gastrointestinal cancers and CAFs is summarized. Activated HH signaling is found in CAFs with elevated expression of $\alpha$ SMA and periostin. NDRG1 reduces CAF-mediated cell migration and the CAFs' activation through inhibition of $\mathrm{HH}$ signaling. TME-derived HIF1 $\alpha$ and CAF-derived TGF $\beta 2$, Gal1, TNF $\alpha$, and IL-1 $\beta$ may activate HH signaling in tumor cells to induce drug resistance. Hedgehog $(\mathrm{HH})$; tumor microenvironment (TME); cancer associated fibroblasts (CAFs); alpha smooth muscle actin ( $\alpha \mathrm{SMA})$; N-myc downstream-regulated gene 1 (NDRG1); hypoxia inducible factor $1 \alpha(\mathrm{HIF} 1 \alpha)$; transforming growth factor $\beta 2$ (TGF $\beta 2$ ); glycan-binding protein galectin-1 (Gal1); tumor necrosis factor $\alpha$ (TNF $\alpha$ ); interleukin-1 $\beta$ (IL-1 $\beta$ ).

Pancreatic ductal adenocarcinoma (PDAC) is characterized by dense stroma that are generally refractory to conventional treatments. Pancreatic stellate cells (PSCs) contribute to this stromal barrier and PDAC progression. The HH pathway plays a vital role in crosstalk between cancer cells and PSCs (Figure 2) [45,46]. Stromal-derived glycan-binding protein galectin-1 (Gal1) [47], tumor necrosis factor $\alpha$ (TNF $\alpha$ ), and interleukin-1 $\beta$ (IL-1 $\beta$ ) [48] could activate $\mathrm{HH}$ signaling in PDAC cells. Moreover, TNF $\alpha$ and IL-1 $\beta$ activated GLI through both SMO and nuclear factor- $\mathrm{KB}(\mathrm{NF}-\mathrm{kB})$, and SMO inhibition did not altogether abolish GLI activation, indicating that inhibition of canonical and non-canonical $\mathrm{HH}$ signaling simultaneously may be more effective in PDAC cells [48]. Activated $\mathrm{HH}$ signaling is also found in stromal cells. SHH protein was found co-expressed with markers of mesenchymal cells, alpha smooth muscle actin ( $\alpha \mathrm{SMA})$, and periostin [49]. N-myc downstream-regulated gene 1 (NDRG1) reduced PSC-mediated cell migration and PSCs' activation through inhibition of HH signaling [46]. Our group found that SMO inhibition significantly altered the gene expression profile of the tumor microenvironment but had no significant effects on cancer cell metastasis. The SMO inhibitor combined with the MEK inhibitor showed a reduced number of metastatic nodules in several mouse models for pancreatic cancer [50]. The SMO inhibitor GDC-0449 sensitized PDAC to gemcitabine [45] and doxorubicin [51].

\section{Crosstalking with Other Pathways}

Studies found that the $\mathrm{HH}$ pathway regulates chemotherapeutic resistance by crosstalking with other pathways in many types of cancer, including gastrointestinal cancers (Figure 3). Yao et al. found that GLI1 was activated by the AKT-mTOR pathway in gastric cancer cells. Inhibitors targeting GLI1 and p-AKT may reverse drug resistance and 
achieve better inhibition than agents targeted against a single molecule [52]. Our group and other researchers found elevated expression of the HH pathway in chemotherapy-resistant colorectal cancer cells [29,53-57]. Besides canonical HH signaling [53,54], GLI was activated by AKT [29] and signal transducer and activator of transcription 3 (STAT3) [55] in colorectal cancers. The activation of the HH signal promoted EMT-related pathways $[53,54]$, and GLI1 could bind to the promoter region of six ABC transporters in colorectal cancers [56].

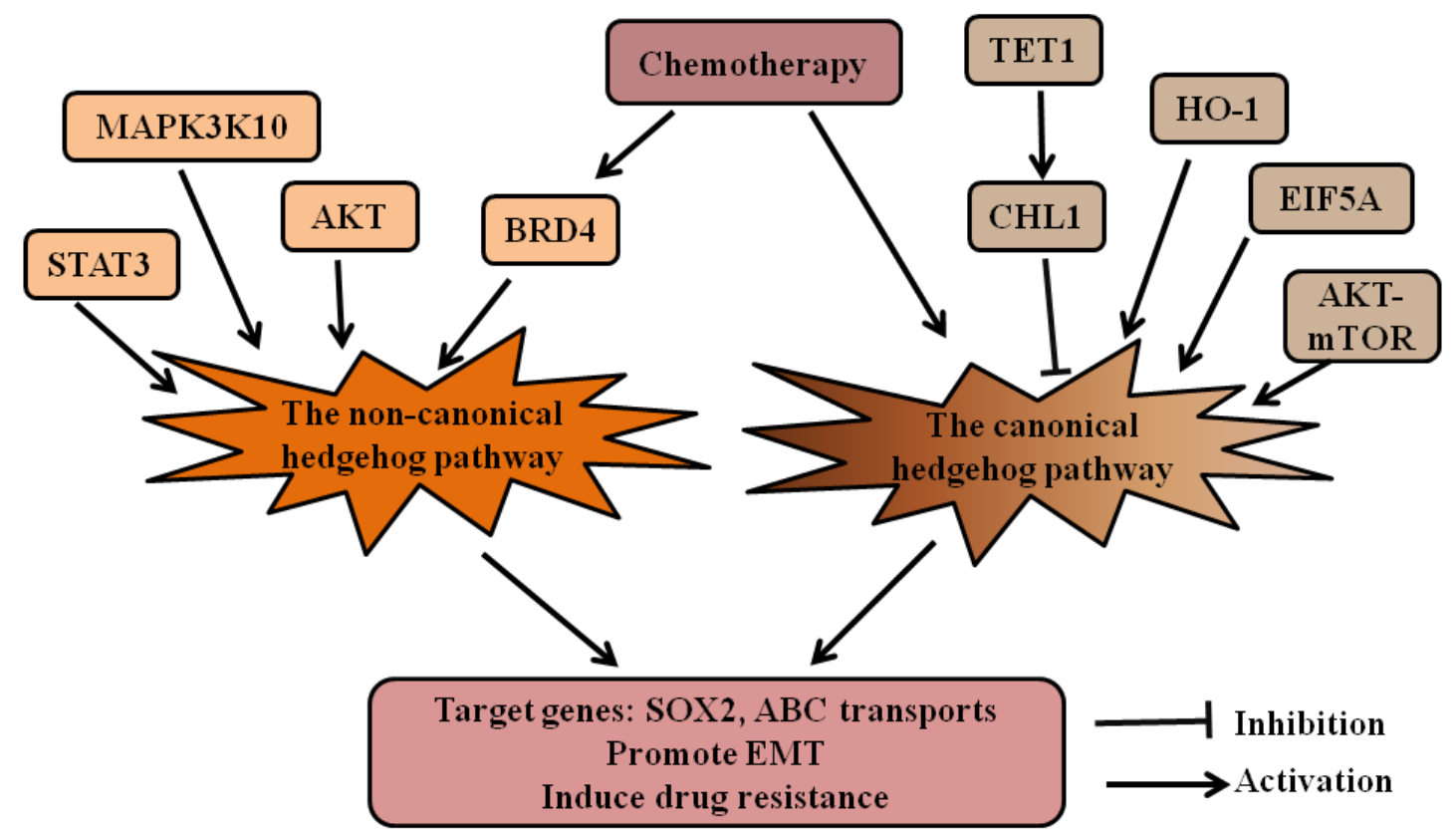

Figure 3. The HH pathway crosstalks with other signaling pathways in gastrointestinal cancers. The crosstalking of the canonical and non-canonical HH pathways with other pathways in drug resistance of gastrointestinal cancers are summarized. In gastrointestinal cancers, HO-1, ATK-mTOR, and EIF5A can activate the canonical HH pathway, while TET1 and CHL1 inhibit the canonical HH pathway. STAT3, MAP3K10, AKT, and BRD4 may activate the non-canonical $\mathrm{HH}$ pathway. Chemotherapy activates the $\mathrm{HH}$ pathway through different mechanisms. The active $\mathrm{HH}$ signaling increases expression of SOX2 and ABC transporters, promotes EMT, and induces drug resistance. Hedgehog (HH); heme oxygenase-1 (HO-1); mammalian target of rapamycin (mTOR); eukaryotic translation initiation factor 5A (EIF5A); signal transducer and activator of transcription 3 (STAT3); mitogen-activated protein kinase 10 (MAP3K10); bromodomain-containing protein 4(BRD4); ATP-binding cassette (ABC) transports; epithelial-mesenchymal transition (EMT).

The most commonly used chemotherapeutic drug for pancreatic cancer is gemcitabine. The role of the $\mathrm{HH}$ pathway in gemcitabine resistance is well-studied (Figure 3). Several molecules, including Heme oxygenase-1 (HO-1) [58], mitogen-activated protein kinase 10 (MAP3K10) [59], and eukaryotic translation initiation factor 5A (EIF5A) [60], increased resistance to gemcitabine through activating the HH pathway. TET1 and CHL1 [61] reversed the gemcitabine resistance by downregulating the $\mathrm{HH}$ pathway. $\mathrm{HH}$ signaling increased resistance to gemcitabine by activating ABCB2 [62]. Our group revealed the GLISOX2 signaling axis for regulation of gemcitabine sensitivity and found direct regulation of SOX2 by GLI transcription factors [35]. Gemcitabine treatment also elevated HH signaling, cancer cell stemness, and EMT-related pathways [63] through upregulation of BRD4 [64]. Recent studies found that Dasatinib [65] and Erlotinib [66] resistance was also associated with $\mathrm{HH}$ signaling, and inhibition of GLI could reduce the resistance to Erlotinib [66].

\section{New Drugs and Therapeutic Strategy}

The HH inhibitors vismodegib and sonidegib have been approved by the Food and Drug Administration to treat recurrent, locally advanced basal cell carcinoma (BCC) or metastatic BCC, or for those who are not eligible for surgery or radiotherapy. The efficacy and safety of vismodegib and sonidegib have been reviewed in [67]. Vismodegib and 
sonidegib are also used in clinical trials for other solid tumors (medulloblastoma, prostate cancer, pancreatic cancer, and small cell lung cancer) and hematologic malignancies (actively reviewed in $[68,69])$. The results from these clinical trials show that the $\mathrm{HH}$ inhibitors only promote treatment efficacy in $\mathrm{HH}$-driven cancers.

Since current therapy is still far from satisfactory, novel drugs and new therapeutic strategies were developed to improve the treatment. Novel $\mathrm{HH}$ inhibitors also have been developed. GDC0449 analog MDB5 [70] and GLI1 inhibitor NanoHHI [71] overcame SMO mutation and improved the treatment effect. Other drugs, such as curcumin, sensitized colorectal cancer to chemotherapy through downregulating HH signaling [72], and Dpc [46], ormeloxifene [73], Patched 1-interacting peptide [74], and metformin [75] targeted $\mathrm{HH}$ signaling was found to reduce the tumor-associated stromal tissue in pancreatic cancers.

Due to dense stromal tissue, chemotherapeutic and targeted drugs, immune cells are hard to get to cancer cells; therefore, targeting stromal cells is a new promising strategy in pancreatic cancers. Since the $\mathrm{HH}$ pathway contributes to the development of the dense stromal tissue, several studies combined SMO inhibitors with either cytotoxic chemotherapeutic drugs [76-78] or a targeted antibody [79] to increase the delivery of the drugs and promote tumor infiltration of the CD8 T cells. Inhibition of the $\mathrm{HH}$ pathway increased intratumoral vasculature density. Some studies found that SMO inhibitors reduced collagen, $\alpha$-SMA, and GLI-1 expression [76,79]. However, another study found that SMO inhibitor did not decrease the $\alpha$-SMA-positive fibroblasts and type I collagen in the stroma [77], indicating more studies should be performed to identify the mechanisms how SMO inhibitors increase the delivery of drugs. Furthermore, research suggested that combined the hepatocyte growth factor (HGF)/c-Met and HH pathways inhibitors overcame the resistance to the single-inhibitor treatment and led to sensitization to the gemcitabine treatment [80]. Despite the promising results above and the excellent responses to sonidegib in a mouse model [81], vismodegib does not show improvement in metastatic pancreatic adenocarcinoma (NCT01088815, NCT01064622, [82]). The preclinical model may not accurately reflect the tumor context of patients; patient-derived xenografts, and maybe in the future, patient-derived 3D culture models with tumor cells and a microenvironment, are better materials for studying the efficacy and mechanisms of action of therapeutic drugs.

\section{Conclusions and Perspectives}

Accumulating data suggest that the $\mathrm{HH}$ pathway plays an important role in chemoresistance in gastrointestinal cancers. CSCs are the well-known cause for drug resistance and are extensively studied in gastric, colorectal, and pancreatic cancers, and the $\mathrm{HH}$ pathway is a promising target for eradicating CSCs. Due to the dense stromal tissue in pancreatic cancers, the role of $\mathrm{HH}$ signaling in PSCs is actively being investigated. Inhibition of the HH pathway in PSCs reduces stromal tissue and increases drug delivery, suggesting that $\mathrm{HH}$ signaling may also play a mechanical role in chemoresistance. However, studies focused on the HH pathway in the TME of gastric and colorectal cancer chemoresistance are relatively scarce. Despite the different pathological characteristics in gastric, colorectal, and pancreatic cancers, the $\mathrm{HH}$ pathway regulates the $\mathrm{ABC}$ transporter family proteins in all three types of cancer.

Studies from gastrointestinal cancers and their CSCs provide evidence for the existence of both canonical and non-canonical HH signaling, which do sound the alarm to us. Inhibition of SMO may not inhibit $\mathrm{HH}$ activation, and this may partially explain the dismal results of vismodegib in some clinical trials for advanced solid tumors. Identifying how $\mathrm{HH}$ signaling is activated, caused by either a ligand-dependent or ligand-independent mechanism, may help us choose the correct inhibitors to attenuate activation of the $\mathrm{HH}$ pathway in different cancer contexts.

Funding: We thank The Well Center for Pediatric Research, Jeff Gordon Research Laboratory, AGA, Healthcare Initiatives, Inc., and CTSI Indiana for support. The research is funded by the National Natural Science Foundation of China (31960153). 
Institutional Review Board Statement: Not applicable.

Informed Consent Statement: Not applicable.

Data Availability Statement: Not applicable.

Conflicts of Interest: The authors declare no conflict of interest.

\section{References}

1. Kong, J.; Siebold, C.; Rohatgi, R. Biochemical mechanisms of vertebrate hedgehog signaling. Development 2019, 146, dev166892. [CrossRef] [PubMed]

2. Yang, L.; Xie, G.; Fan, Q.; Xie, J. Activation of the hedgehog-signaling pathway in human cancer and the clinical implications. Oncogene 2010, 29, 469-481. [CrossRef] [PubMed]

3. Kinzler, K.; Vogelstein, B. The GLI gene encodes a nuclear protein which binds specific sequences in the human genome. Mol. Cell. Biol. 1990, 10, 634-642. [CrossRef]

4. Sasaki, H.; Hui, C.; Nakafuku, M.; Kondoh, H. A binding site for Gli proteins is essential for HNF-3beta floor plate enhancer activity in transgenics and can respond to Shh in vitro. Development 1997, 124, 1313-1322. [PubMed]

5. Ji, Z.; Mei, F.; Xie, J.; Cheng, X. Oncogenic KRAS activates hedgehog signaling pathway in pancreatic cancer cells. J. Biol. Chem. 2007, 282, 14048-14055. [CrossRef] [PubMed]

6. Seto, M.; Ohta, M.; Asaoka, Y.; Ikenoue, T.; Tada, M.; Miyabayashi, K.; Mohri, D.; Tanaka, Y.; Ijichi, H.; Tateishi, K.; et al. Regulation of the hedgehog signaling by the mitogen-activated protein kinase cascade in gastric cancer. Mol. Carcinog. 2009, 48, 703-712. [CrossRef] [PubMed]

7. Dennler, S.; André, J.; Alexaki, I.; Li, A.; Magnaldo, T.; ten Dijke, P.; Wang, X.; Verrecchia, F.; Mauviel, A. Induction of sonic hedgehog mediators by transforming growth factor-beta: Smad3-dependent activation of Gli2 and Gli1 expression in vitro and in vivo. Cancer Res. 2007, 67, 6981-6986. [CrossRef] [PubMed]

8. Stecca, B.; Mas, C.; Clement, V.; Zbinden, M.; Correa, R.; Piguet, V.; Beermann, F.; Ruiz i Altaba, A. Melanomas require HEDGEHOG-GLI signaling regulated by interactions between GLI1 and the RAS-MEK/AKT pathways. Proc. Natl. Acad. Sci. USA 2007, 104, 5895-5900. [CrossRef]

9. Cai, Q.; Li, J.; Gao, T.; Xie, J.; Evers, B. Protein kinase Cdelta negatively regulates hedgehog signaling by inhibition of Gli1 activity. J. Biol. Chem. 2009, 284, 2150-2158. [CrossRef]

10. Pietrobono, S.; Gaudio, E.; Gagliardi, S.; Zitani, M.; Carrassa, L.; Migliorini, F.; Petricci, E.; Manetti, F.; Makukhin, N.; Bond, A.; et al. Targeting non-canonical activation of GLI1 by the SOX2-BRD4 transcriptional complex improves the efficacy of HEDGEHOG pathway inhibition in melanoma. Oncogene 2021, 40, 3799-3814. [CrossRef]

11. Wijdeven, R.; Pang, B.; Assaraf, Y.; Neefjes, J. Old drugs, novel ways out: Drug resistance toward cytotoxic chemotherapeutics. Drug Resist. Updates Rev. Comment. Antimicrob. Anticancer Chemother. 2016, 28, 65-81. [CrossRef]

12. Alexa-Stratulat, T.; Pešić, M.; Gašparović, A.; Trougakos, I.; Riganti, C. What sustains the multidrug resistance phenotype beyond ABC efflux transporters? Looking beyond the tip of the iceberg. Drug Resist. Updates Rev. Comment. Antimicrob. Anticancer Chemother. 2019, 46, 100643. [CrossRef]

13. Martins-Neves, S.; Cleton-Jansen, A.; Gomes, C. Therapy-induced enrichment of cancer stem-like cells in solid human tumors: Where do we stand? Pharmacol. Res. 2018, 137, 193-204. [CrossRef]

14. Katoh, M. Genomic testing, tumor microenvironment and targeted therapy of Hedgehog-related human cancers. Clin. Sci. 2019, 133, 953-970. [CrossRef] [PubMed]

15. Uzunparmak, B.; Sahin, I. Pancreatic cancer microenvironment: A current dilemma. Clin. Transl. Med. 2019, 8, 2. [CrossRef]

16. Sari, I.; Phi, L.; Jun, N.; Wijaya, Y.; Lee, S.; Kwon, H. Hedgehog signaling in cancer: A prospective therapeutic target for eradicating cancer stem cells. Cells 2018, 7, 208. [CrossRef] [PubMed]

17. Clara, J.; Monge, C.; Yang, Y.; Takebe, N. Targeting signalling pathways and the immune microenvironment of cancer stem cells-A clinical update. Nat. Rev. Clin. Oncol. 2020, 17, 204-232. [CrossRef]

18. Yang, L.; Shi, P.; Zhao, G.; Xu, J.; Peng, W.; Zhang, J.; Zhang, G.; Wang, X.; Dong, Z.; Chen, F.; et al. Targeting cancer stem cell pathways for cancer therapy. Signal Transduct. Target. Ther. 2020, 5, 8. [CrossRef] [PubMed]

19. Yu, B.; Gu, D.; Zhang, X.; Li, J.; Liu, B.; Xie, J. GLI1-mediated regulation of side population is responsible for drug resistance in gastric cancer. Oncotarget 2017, 8, 27412-27427. [CrossRef] [PubMed]

20. Yoon, C.; Park, D.; Schmidt, B.; Thomas, N.; Lee, H.; Kim, T.; Janjigian, Y.; Cohen, D.; Yoon, S. CD44 expression denotes a subpopulation of gastric cancer cells in which Hedgehog signaling promotes chemotherapy resistance. Clin. Cancer Res. Off. J. Am. Assoc. Cancer Res. 2014, 20, 3974-3988. [CrossRef] [PubMed]

21. Zhang, X.; Hua, R.; Wang, X.; Huang, M.; Gan, L.; Wu, Z.; Zhang, J.; Wang, H.; Cheng, Y.; Li, J.; et al. Identification of stem-like cells and clinical significance of candidate stem cell markers in gastric cancer. Oncotarget 2016, 7, 9815-9831. [CrossRef] [PubMed]

22. Song, Z.; Yue, W.; Wei, B.; Wang, N.; Li, T.; Guan, L.; Shi, S.; Zeng, Q.; Pei, X.; Chen, L. Sonic hedgehog pathway is essential for maintenance of cancer stem-like cells in human gastric cancer. PLoS ONE 2011, 6, e17687. [CrossRef] [PubMed]

23. Nishikawa, S.; Konno, M.; Hamabe, A.; Hasegawa, S.; Kano, Y.; Ohta, K.; Fukusumi, T.; Sakai, D.; Kudo, T.; Haraguchi, N.; et al. Aldehyde dehydrogenase high gastric cancer stem cells are resistant to chemotherapy. Int. J. Oncol. 2013, 42, 1437-1442. [CrossRef] 
24. Xu, M.; Gong, A.; Yang, H.; George, S.; Jiao, Z.; Huang, H.; Jiang, X.; Zhang, Y. Sonic hedgehog-glioma associated oncogene homolog 1 signaling enhances drug resistance in CD44(+)/Musashi-1(+) gastric cancer stem cells. Cancer Lett. 2015, 369, 124-133. [CrossRef] [PubMed]

25. Pádua, D.; Barros, R.; Amaral, A.; Mesquita, P.; Freire, A.; Sousa, M.; Maia, A.; Caiado, I.; Fernandes, H.; Pombinho, A.; et al. A SOX2 reporter system identifies gastric cancer stem-like cells sensitive to monensin. Cancers 2020, 12, 495. [CrossRef]

26. Yu, B.; Gu, D.; Zhang, X.; Liu, B.; Xie, J. The role of GLI2-ABCG2 signaling axis for 5Fu resistance in gastric cancer. J. Genet. Genom. = Yi Chuan Xue Bao 2017, 44, 375-383. [CrossRef] [PubMed]

27. Ma, H.; Tian, Y.; Yu, X. Targeting smoothened sensitizes gastric cancer to chemotherapy in experimental models. Med Sci. Monit. Int. Med. J. Exp. Clin. Res. 2017, 23, 1493-1500. [CrossRef]

28. Batsaikhan, B.; Yoshikawa, K.; Kurita, N.; Iwata, T.; Takasu, C.; Kashihara, H.; Shimada, M. Cyclopamine decreased the expression of Sonic Hedgehog and its downstream genes in colon cancer stem cells. Anticancer Res. 2014, 34, 6339-6344. [PubMed]

29. Yang, Z.; Zhang, C.; Qi, W.; Cui, Y.; Xuan, Y. GLI1 promotes cancer stemness through intracellular signaling pathway $\mathrm{PI3K} / \mathrm{Akt} / \mathrm{NF} \kappa \mathrm{B}$ in colorectal adenocarcinoma. Exp. Cell Res. 2018, 373, 145-154. [CrossRef] [PubMed]

30. Ren, Y.; Deng, R.; Cai, R.; Lu, X.; Luo, Y.; Wang, Z.; Zhu, Y.; Yin, M.; Ding, Y.; Lin, J. TUSC3 induces drug resistance and cellular stemness via Hedgehog signaling pathway in colorectal cancer. Carcinogenesis 2020, 41, 1755-1766. [CrossRef]

31. Zhou, H.; Xiong, Y.; Peng, L.; Wang, R.; Zhang, H.; Fu, Z. LncRNA-cCSC1 modulates cancer stem cell properties in colorectal cancer via activation of the Hedgehog signaling pathway. J. Cell. Biochem. 2020, 121, 2510-2524. [CrossRef] [PubMed]

32. Usui, T.; Sakurai, M.; Umata, K.; Elbadawy, M.; Ohama, T.; Yamawaki, H.; Hazama, S.; Takenouchi, H.; Nakajima, M.; Tsunedomi, R.; et al. Hedgehog signals mediate anti-cancer drug resistance in three-dimensional primary colorectal cancer organoid culture. Int. J. Mol. Sci. 2018, 19, 1098. [CrossRef]

33. Huang, F.; Zhuan-Sun, Y.; Zhuang, Y.; Wei, S.; Tang, J.; Chen, W.; Zhang, S. Inhibition of hedgehog signaling depresses self-renewal of pancreatic cancer stem cells and reverses chemoresistance. Int. J. Oncol. 2012, 41, 1707-1714. [CrossRef]

34. Miyazaki, Y.; Matsubara, S.; Ding, Q.; Tsukasa, K.; Yoshimitsu, M.; Kosai, K.; Takao, S. Efficient elimination of pancreatic cancer stem cells by hedgehog/GLI inhibitor GANT61 in combination with mTOR inhibition. Mol. Cancer 2016, 15, 49. [CrossRef] [PubMed]

35. Jia, Y.; Gu, D.; Wan, J.; Yu, B.; Zhang, X.; Chiorean, E.; Wang, Y.; Xie, J. The role of GLI-SOX2 signaling axis for gemcitabine resistance in pancreatic cancer. Oncogene 2019, 38, 1764-1777. [CrossRef]

36. Haque, I.; De, A.; Majumder, M.; Mehta, S.; McGregor, D.; Banerjee, S.; Van Veldhuizen, P.; Banerjee, S. The matricellular protein CCN1/Cyr61 is a critical regulator of Sonic Hedgehog in pancreatic carcinogenesis. J. Biol. Chem. 2012, 287, 38569-38579. [CrossRef] [PubMed]

37. Zhang, Y.; Xue, X.; Zhao, X.; Qin, L.; Shen, Y.; Dou, H.; Sun, J.; Wang, T.; Yang, D. Vasohibin 2 promotes malignant behaviors of pancreatic cancer cells by inducing epithelial-mesenchymal transition via Hedgehog signaling pathway. Cancer Med. 2018, 7, 5567-5576. [CrossRef]

38. Song, L.; Chen, X.; Gao, S.; Zhang, C.; Qu, C.; Wang, P.; Liu, L. Ski modulate the characteristics of pancreatic cancer stem cells via regulating sonic hedgehog signaling pathway. Tumour Biol. J. Int. Soc. Oncodevelopmental Biol. Med. 2016, 37, 16115-16125. [CrossRef]

39. Mueller, M.; Hermann, P.; Witthauer, J.; Rubio-Viqueira, B.; Leicht, S.; Huber, S.; Ellwart, J.; Mustafa, M.; Bartenstein, P.; D’Haese, J.; et al. Combined targeted treatment to eliminate tumorigenic cancer stem cells in human pancreatic cancer. Gastroenterology 2009, 137, 1102-1113. [CrossRef]

40. Yao, H.; Sun, L.; Li, J.; Zhou, X.; Li, R.; Shao, R.; Zhang, Y.; Li, L. A Novel Therapeutic siRNA Nanoparticle Designed for Dual-Targeting CD44 and Gli1 of Gastric Cancer Stem Cells. Int. J. Nanomed. 2020, 15, 7013-7034. [CrossRef]

41. Dong, H.; Liu, H.; Zhou, W.; Zhang, F.; Li, C.; Chen, J.; Tan, C.; Tang, B.; Yu, P. GLI1 activation by non-classical pathway integrin $\alpha \beta /$ ERK1/2 maintains stem cell-like phenotype of multicellular aggregates in gastric cancer peritoneal metastasis. Cell Death Dis. 2019, 10, 574. [CrossRef] [PubMed]

42. Schneider, G.; Schmidt-Supprian, M.; Rad, R.; Saur, D. Tissue-specific tumorigenesis: Context matters. Nat. Rev. Cancer 2017, 17, 239-253. [CrossRef]

43. Hanna, A.; Shevde, L. Hedgehog signaling: Modulation of cancer properies and tumor mircroenvironment. Mol. Cancer 2016, 15, 24. [CrossRef]

44. Tang, Y.; Chen, Y.; Bao, Y.; Mahara, S.; Yatim, S.; Oguz, G.; Lee, P.; Feng, M.; Cai, Y.; Tan, E.; et al. Hypoxic tumor microenvironment activates GLI2 via HIF- $1 \alpha$ and TGF- $\beta 2$ to promote chemoresistance in colorectal cancer. Proc. Natl. Acad. Sci. USA 2018, 115, E5990-E5999. [CrossRef]

45. Khan, M.; Srivastava, S.; Zubair, H.; Patel, G.; Arora, S.; Khushman, M.; Carter, J.; Gorman, G.; Singh, S.; Singh, A. Co-targeting of CXCR4 and hedgehog pathways disrupts tumor-stromal crosstalk and improves chemotherapeutic efficacy in pancreatic cancer. J. Biol. Chem. 2020, 295, 8413-8424. [CrossRef] [PubMed]

46. Geleta, B.; Park, K.; Jansson, P.; Sahni, S.; Maleki, S.; Xu, Z.; Murakami, T.; Pajic, M.; Apte, M.; Richardson, D.; et al. Breaking the cycle: Targeting of NDRG1 to inhibit bi-directional oncogenic cross-talk between pancreatic cancer and stroma. FASEB J. Off. Publ. Fed. Am. Soc. Exp. Biol. 2021, 35, e21347. [CrossRef] 
47. Martínez-Bosch, N.; Fernández-Barrena, M.; Moreno, M.; Ortiz-Zapater, E.; Munné-Collado, J.; Iglesias, M.; André, S.; Gabius, H.; Hwang, R.; Poirier, F.; et al. Galectin-1 drives pancreatic carcinogenesis through stroma remodeling and Hedgehog signaling activation. Cancer Res. 2014, 74, 3512-3524. [CrossRef] [PubMed]

48. Wang, Y.; Jin, G.; Li, Q.; Wang, Z.; Hu, W.; Li, P.; Li, S.; Wu, H.; Kong, X.; Gao, J.; et al. Hedgehog signaling non-canonical activated by pro-inflammatory cytokines in pancreatic ductal adenocarcinoma. J. Cancer 2016, 7, 2067-2076. [CrossRef]

49. Saini, F.; Argent, R.; Grabowska, A. Sonic hedgehog ligand: A role in formation of a mesenchymal niche in human pancreatic ductal adenocarcinoma. Cells 2019, 8, 424. [CrossRef]

50. Gu, D.; Lin, H.; Zhang, X.; Fan, Q.; Chen, S.; Shahda, S.; Liu, Y.; Sun, J.; Xie, J. Simultaneous inhibition of MEK and Hh signaling reduces pancreatic cancer metastasis. Cancers 2018, 10, 403. [CrossRef] [PubMed]

51. Zhou, Q.; Zhou, Y.; Liu, X.; Shen, Y. GDC-0449 improves the antitumor activity of nano-doxorubicin in pancreatic cancer in a fibroblast-enriched microenvironment. Sci. Rep. 2017, 7, 13379. [CrossRef]

52. Yao, Y.; Zhou, D.; Shi, D.; Zhang, H.; Zhan, S.; Shao, X.; Sun, K.; Sun, L.; Wu, G.; Tian, K.; et al. GLI1 overexpression promotes gastric cancer cell proliferation and migration and induces drug resistance by combining with the AKT-mTOR pathway. Biomed. Pharmacother. $=$ Biomed . Pharmacother. 2019, 111, 993-1004. [CrossRef]

53. Lai, Q.; Li, Q.; He, C.; Fang, Y.; Lin, S.; Cai, J.; Ding, J.; Zhong, Q.; Zhang, Y.; Wu, C.; et al. CTCF promotes colorectal cancer cell proliferation and chemotherapy resistance to 5-FU via the P53-Hedgehog axis. Aging 2020, 12, 16270-16293. [CrossRef] [PubMed]

54. Liu, Y.; DU, F.; Zhao, Q.; Jin, J.; Ma, X.; Li, H. Acquisition of 5-fluorouracil resistance induces epithelial-mesenchymal transitions through the Hedgehog signaling pathway in HCT-8 colon cancer cells. Oncol. Lett. 2015, 9, 2675-2679. [CrossRef]

55. Park, S.; Jo, M.; Kim, B.; Jeong, Y.; Na, Y.; Kim, J.; Jeong, S.; Yun, H.; Kim, D.; Kim, B.; et al. Sonic hedgehog pathway activation is associated with cetuximab resistance and EPHB3 receptor induction in colorectal cancer. Theranostics 2019, 9, 2235-2251. [CrossRef]

56. Po, A.; Citarella, A.; Catanzaro, G.; Besharat, Z.; Trocchianesi, S.; Gianno, F.; Sabato, C.; Moretti, M.; De Smaele, E.; Vacca, A.; et al. Hedgehog-GLI signalling promotes chemoresistance through the regulation of ABC transporters in colorectal cancer cells. Sci. Rep. 2020, 10, 13988. [CrossRef] [PubMed]

57. Zhang, L.; Song, R.; Gu, D.; Zhang, X.; Yu, B.; Liu, B.; Xie, J. The role of GLI1 for 5-Fu resistance in colorectal cancer. Cell Biosci. 2017, 7, 17. [CrossRef]

58. Han, L.; Jiang, J.; Ma, Q.; Wu, Z.; Wang, Z. The inhibition of heme oxygenase-1 enhances the chemosensitivity and suppresses the proliferation of pancreatic cancer cells through the SHH signaling pathway. Int. J. Oncol. 2018, 52, 2101-2109. [CrossRef]

59. An, Y.; Cai, B.; Chen, J.; Lv, N.; Yao, J.; Xue, X.; Tu, M.; Tang, D.; Wei, J.; Jiang, K.; et al. MAP3K10 promotes the proliferation and decreases the sensitivity of pancreatic cancer cells to gemcitabine by upregulating Gli-1 and Gli-2. Cancer Lett. 2013, 329, 228-235. [CrossRef] [PubMed]

60. Wang, Z.; Jiang, J.; Qin, T.; Xiao, Y.; Han, L. EIF5A regulates proliferation and chemoresistance in pancreatic cancer through the sHH signalling pathway. J. Cell. Mol. Med. 2019, 23, 2678-2688. [CrossRef]

61. Li, H.; Jiang, W.; Liu, X.; Yuan, L.; Li, T.; Li, S.; Xu, S.; Zhang, W.; Gao, H.; Han, X.; et al. TET1 downregulates epithelialmesenchymal transition and chemoresistance in PDAC by demethylating CHL1 to inhibit the Hedgehog signaling pathway. Oncogene 2020, 39, 5825-5838. [CrossRef] [PubMed]

62. Xu, M.; Li, L.; Liu, Z.; Jiao, Z.; Xu, P.; Kong, X.; Huang, H.; Zhang, Y. ABCB2 (TAP1) as the downstream target of SHH signaling enhances pancreatic ductal adenocarcinoma drug resistance. Cancer Lett. 2013, 333, 152-158. [CrossRef] [PubMed]

63. Quint, K.; Tonigold, M.; Di Fazio, P.; Montalbano, R.; Lingelbach, S.; Rückert, F.; Alinger, B.; Ocker, M.; Neureiter, D. Pancreatic cancer cells surviving gemcitabine treatment express markers of stem cell differentiation and epithelial-mesenchymal transition. Int. J. Oncol. 2012, 41, 2093-2102. [CrossRef]

64. Wang, Y.; Sui, Y.; Yan, K.; Wang, L.; Wang, F.; Zhou, J. BRD4 promotes pancreatic ductal adenocarcinoma cell proliferation and enhances gemcitabine resistance. Oncol. Rep. 2015, 33, 1699-1706. [CrossRef] [PubMed]

65. Chien, W.; Sudo, M.; Ding, L.; Sun, Q.; Wuensche, P.; Lee, K.; Hattori, N.; Garg, M.; Xu, L.; Zheng, Y.; et al. Functional genomewide screening identifies targets and pathways sensitizing pancreatic cancer cells to dasatinib. J. Cancer 2018, 9, $4762-4773$. [CrossRef]

66. Ghanbari, A.; Cheraghzadeh, Z.; Mahmoudi, R.; Zibara, K.; Hosseini, E. GLI inhibitors overcome Erlotinib resistance in human pancreatic cancer cells by modulating E-cadherin. J. Chemother. 2019, 31, 141-149. [CrossRef]

67. Migden, M.; Farberg, A.S.; Dummer, R.; Squittieri, N.; Hanke, C.W. A Review of Hedgehog Inhibitors Sonidegib and Vismodegib for Treatment of Advanced Basal Cell Carcinoma. J. Drugs Dermatol. JDD 2021, 20, 156-165. [CrossRef]

68. Cortes, J.E.; Gutzmer, R.; Kieran, M.W.; Solomon, J.A. Hedgehog signaling inhibitors in solid and hematological cancers. Cancer Treat Rev. 2019, 76, 41-50. [CrossRef]

69. Xie, H.; Paradise, B.D.; Ma, W.W.; Fernandez-Zapico, M.E. Recent advances in the clinical targeting of Hedgehog/GLI signaling in cancer. Cells 2019, 8, 394. [CrossRef]

70. Kumar, V.; Chaudhary, A.; Dong, Y.; Zhong, H.; Mondal, G.; Lin, F.; Kumar, V.; Mahato, R. Design, synthesis and biological evaluation of novel hedgehog inhibitors for treating pancreatic cancer. Sci. Rep. 2017, 7, 1665. [CrossRef]

71. Chenna, V.; Hu, C.; Pramanik, D.; Aftab, B.; Karikari, C.; Campbell, N.; Hong, S.; Zhao, M.; Rudek, M.; Khan, S.; et al. A polymeric nanoparticle encapsulated small-molecule inhibitor of Hedgehog signaling (NanoHHI) bypasses secondary mutational resistance to Smoothened antagonists. Mol. Cancer Ther. 2012, 11, 165-173. [CrossRef] 
72. Ramasamy, T.; Ayob, A.; Myint, H.; Thiagarajah, S.; Amini, F. Targeting colorectal cancer stem cells using curcumin and curcumin analogues: Insights into the mechanism of the therapeutic efficacy. Cancer Cell Int. 2015, 15, 96. [CrossRef]

73. Khan, S.; Ebeling, M.; Chauhan, N.; Thompson, P.; Gara, R.; Ganju, A.; Yallapu, M.; Behrman, S.; Zhao, H.; Zafar, N.; et al. Ormeloxifene suppresses desmoplasia and enhances sensitivity of gemcitabine in pancreatic cancer. Cancer Res. 2015, 75, 2292-2304. [CrossRef] [PubMed]

74. Oyama, Y.; Onishi, H.; Koga, S.; Murahashi, M.; Ichimiya, S.; Nakayama, K.; Fujimura, A.; Kawamoto, M.; Imaizumi, A.; Umebayashi, M.; et al. Patched 1-interacting Peptide Represses Fibrosis in Pancreatic Cancer to Augment the Effectiveness of Immunotherapy. J. Immunother. 2020, 43, 121-133. [CrossRef] [PubMed]

75. Qian, W.; Li, J.; Chen, K.; Jiang, Z.; Cheng, L.; Zhou, C.; Yan, B.; Cao, J.; Ma, Q.; Duan, W. Metformin suppresses tumor angiogenesis and enhances the chemosensitivity of gemcitabine in a genetically engineered mouse model of pancreatic cancer. Life Sci. 2018, 208, 253-261. [CrossRef] [PubMed]

76. Wang, L.; Liu, X.; Zhou, Q.; Sui, M.; Lu, Z.; Zhou, Z.; Tang, J.; Miao, Y.; Zheng, M.; Wang, W.; et al. Terminating the criminal collaboration in pancreatic cancer: Nanoparticle-based synergistic therapy for overcoming fibroblast-induced drug resistance. Biomaterials 2017, 144, 105-118. [CrossRef] [PubMed]

77. Zhao, J.; Xiao, Z.; Li, T.; Chen, H.; Yuan, Y.; Wang, Y.; Hsiao, C.; Chow, D.; Overwijk, W.; Li, C. Stromal modulation reverses primary resistance to immune checkpoint blockade in pancreatic cancer. ACS Nano 2018, 12, 9881-9893. [CrossRef]

78. Olive, K.; Jacobetz, M.; Davidson, C.; Gopinathan, A.; McIntyre, D.; Honess, D.; Madhu, B.; Goldgraben, M.; Caldwell, M.; Allard D.; et al. Inhibition of Hedgehog signaling enhances delivery of chemotherapy in a mouse model of pancreatic cancer. Science 2009, 324, 1457-1461. [CrossRef] [PubMed]

79. Wang, J.; Chan, D.; Sen, A.; Ma, W.; Straubinger, R. Tumor priming by SMO inhibition enhances antibody delivery and efficacy in a pancreatic ductal adenocarcinoma model. Mol. Cancer Ther. 2019, 18, 2074-2084. [CrossRef]

80. Rucki, A.; Xiao, Q.; Muth, S.; Chen, J.; Che, X.; Kleponis, J.; Sharma, R.; Anders, R.; Jaffee, E.; Zheng, L. Dual inhibition of hedgehog and c-Met pathways for pancreatic cancer treatment. Mol. Cancer Ther. 2017, 16, 2399-2409. [CrossRef]

81. Fendrich, V.; Wiese, D.; Waldmann, J.; Lauth, M.; Heverhagen, A.E.; Rehm, J.; Bartsch, D.K. Hedgehog inhibition with the orally bioavailable Smo antagonist LDE225 represses tumor growth and prolongs survival in a transgenic mouse model of islet cell neoplasms. Ann. Surg. 2011, 254, 818-823, discussion 823. [CrossRef] [PubMed]

82. McCleary-Wheeler, A.L.; Carr, R.M.; Palmer, S.R.; Smyrk, T.C.; Allred, J.B.; Almada, L.L.; Tolosa, E.J.; Lamberti, M.J.; Marks, D.L.; Borad, M.J.; et al. Phase 1 trial of Vismodegib and Erlotinib combination in metastatic pancreatic cancer. Pancreatol. Off. J. Int. Assoc. Pancreatol. 2020, 20, 101-109. [CrossRef] [PubMed] 